\title{
Covid-19, economic activity and formal employment. A look at the effects of the pandemic in México and Nayarit, 2020
}

\section{Covid-19, actividad económica y empleo formal. Una mirada a los efectos de la pandemia en México y Nayarit, 2020}

\author{
MENDOZA-ALVARADO, Juan José*†, ROBLES-ZEPEDA, Francisco Javier and SÁNCHEZ- \\ GÓMEZ, Sara Alejandra
}

Universidad Autónoma de Nayarit, Unidad Académica de Economía

ID $1^{\text {st }}$ Author: Juan José, Mendoza-Alvarado / ORC ID: 0000-0002-1129-6981, CVU CONACYT ID: 72532

ID $1^{\text {st }}$ Coauthor: Francisco Javier, Robles-Zepeda / ORC ID: 0000-0003-1306-265X

ID $2^{\text {nd }}$ Coauthor: Sara Alejandra, Sánchez-Gómez

DOI: $10.35429 / J M M E .2020 .7 .4 .28 .42$

Received August 25, 2020; Accepted December 14, 2020

\begin{abstract}
The objective of this writing is to document the effects of Covid-19 on economic activity and employment in Mexico and Nayarit. Economic Science, through macroeconomic analysis, offers an explanatory framework in relation to the proposed object of study: Neoclassical and Post-Keynesian theories precepts are reviewed. Due to its effects in Mexico and Nayarit, we are facing one of the deepest economic and labor crises in our economic history. There is a $-21.6 \%$ drop in production in Mexico in May and a drop of $-23.1 \%$ in the case of Nayarit in the second quarter of 2020 . In relation to formal employment, a loss of 925,490 jobs are recorded as of July for Mexico as a whole and 17,181 jobs for Nayarit as of April 2020.
\end{abstract}

Covid-19, Supply shock, Economic Activity, Formal employment

\begin{abstract}
Resumen
El objetivo del presente escrito consiste en documentar los efectos del Covid-19 sobre la actividad económica y el empleo en México y en Nayarit. La Ciencia Económica, a través del análisis macroeconómico ofrece un marco explicativo en relación con el objeto de estudio propuesto; se pasan revista a los preceptos de la teoría neoclásica y de la teoría post-keynesiana. Por sus efectos en México y en Nayarit, estamos frente a una de las crisis económicas y laborales más profundas de nuestra historia económica. Se contabilizan una caída de $21.6 \%$ de la producción en México en el mes de mayo y una de $-23.1 \%$ para el caso de Nayarit en el segundo trimestre de 2020. En relación con el empleo formal, se contabilizan una pérdida de 925,490 empleos al mes de julio para México en su conjunto y de 17,181 empleos para Nayarit al mes de abril de 2020.
\end{abstract}

Covid-19, Choque de oferta, Actividad Económica, Empleo formal

Citation: MENDOZA-ALVARADO, Juan José, ROBLES-ZEPEDA, Francisco Javier and SÁNCHEZ-GÓMEZ, Sara Alejandra. Covid-19, economic activity and formal employment. A look at the effects of the pandemic in México and Nayarit, 2020. RINOE Journal-Macroeconomics and monetary economy. 2020. 4-7: 28-42

\footnotetext{
* Correspondence to Author (email: jmendoza@uan.edu.mx)

$\dagger$ Researcher contributing first author.
} 


\section{Introduction}

The world faces, from December 2019 to the present day, a multi-dimensional shock resulting from the outbreak of the SARS-CoV2 virus popularly known as COVID-19 or coronavirus. The effects of this shock also affect the world of production, distribution and circulation of goods and services in the world (extraction and consumption of gasoline and gas, commerce, transport, tourism, hotels, food preparation, etc.) as areas of human interaction (education, health, sports, nightlife, social events -birthdays, baptisms, weddings and funerals-, sports competitions -suspension of attendance at the stadiums of the professional foot-ball leagues, the NBA, American leagues and national baseball, professional box, etc.-), that the increase in uncertainty and risk associated with the functioning of financial markets, transition to new forms of labor relationship such as work at home and increase in family violence. A true revolution, of human interaction in the world of production and of social interaction in the world.

Two of the strongest negative effects of the measures of distancing and suspension of non-essential activities - designed to contain the pandemic - have been the fall in economic activity and employment. The objective of this document is to document the effects of Covid-19 on economic activity and formal employment in Mexico and Nayarit.

\section{Economic Science, through} macroeconomic analysis, offers an explanatory framework in relation to the phenomenon we are currently experiencing. This explanatory framework is not unique or homogeneous, rather it is diverse and not singular. For the neoclassical theory, for example, in relation to temporary changes in the production function, according to Barro (1986) "we can think of the bad weather that reduces coffee production in Brazil or the political problems that reduce agricultural production in Poland. Recently, this type of alteration has been called 'supply shocks' ". From this perspective, natural disasters such as earthquakes, tsunami, droughts, floods, pandemics, etc. they constitute supply shocks that have a negative impact on the production function, contracting the supply of goods and people's wealth.
In Barro's perspective, the decrease in wealth and consumption resulting from a negative supply shock would have a positive effect on labor effort, however, the latter would be less than the total negative effect on the supply of goods. Also, in this same perspective, said "supply shocks" have an unpredictable, casuistic or random character.

On the other hand, from a PostKeynesian perspective, according to KenBenedict (2020) "actions to stop the spread of the new coronavirus COVID-19 are drastically reducing economic activity, leaving people without work, exerting pressure significant on companies and threatens a deep recession ". Unlike the neoclassical perspective, postKeynesian thinking emphasizes the negative effects that pandemic containment measures have on demand, as well as the fact that the spread of the disease around the world is disrupting global supply chains.

Notwithstanding the difference in the emphasis that the schools of economic thought place on the supply or demand aspects, it is clear that the pandemic and the associated measures to confront it: social distancing and suspension of non-essential activities, affect the goods market both on the supply and demand sides, as well as the labor market. Documenting the relationship between the variables previously described in Mexico and Nayarit is the purpose of this work. Its implications in terms of public policy to safeguard the productive apparatus (Micro, small and medium enterprises) and employment are essential to preserve the well-being of Mexicans.

The first section presents a brief review of the relevant literature in relation to Covid-19, economic activity and formal employment. Next, the basic data of the pandemic in the world and between states in Mexico are documented. With this last action the state of Nayarit is visible in the world context. Likewise, the behavior of the global indicator of economic activity in Mexico is reviewed at a sectoral level, detecting the existence of endogenous processes of disinvestment and medium-term decrease existing prior to the public health crisis that, when combined, have resulted to an economic and employment crisis greater than the economic-financial crisis of 2009 and only comparable to that of $1929-1932$ of the 20th century. 
Finally, a section is presented where the indicators available for the analysis of the 2020 situation of the economy and formal employment in Nayarit are reviewed.

\section{Review of relevant literature}

Over the course of 2020, a large number of studies have been published in relation to COVID-19 and the Economy. It is out of the scope of this research to review in its extension said literature which addresses from the design of optimal mitigation policies (Acemoglu, Chernozukov, Werning and Winston, 2020) to the impact of COVID-19 on gender equality (Alon, Doepke, Olmstead-Rumsey and Tertilt, 2020). Instead, it is proposed to highlight a group of works that from a macroeconomic perspective highlight the effects of the pandemic on economic activity and employment.

The dominant body of economic thought in the Western world during the 1940-1970 period was strongly influenced by Keynesianism. This school of analysis, as a result of the crisis of 1929-1932, identified the insufficiency of effective demand as an important element to explain the fluctuations of the business cycle. In this perspective, economic policy actions through government action constitute a possibility to influence the behavior of economic and financial activity.

Shapiro (1987) argues that "following Keynes, much of the macroeconomic analysis neglected the role of the supply side. In periods when supply shocks are minimal, doing so provides an adequate, if incomplete, understanding of economic fluctuations. The emphasis on effective demand was inadequate for forecasting, analyzing and prescribing policies in the face of supply shocks in the 1970s ". During the 1970s, the emphasis on economic analysis would shift towards the importance of supply aspects in the behavior of the cycle and economic growth.

Paraphrasing Solow (1980), one must ask: what made the 1970s so different from other years?
After two years in which the consumer price index (CPI) rose at an annual rate of $3.4 \%$, it jumped to $8.8 \%$ in the four quarters of 1973. Much of that reflected the increase in food prices; the non-food commodity component of the CPI increased by only 5\% in 1973, but even that was double the 1972 rate. The food component of the CPI, which had risen $4.7 \%$ in 1972 , rose by $20,1 \%$ in the four quarters of 1973 (Solow, 1980, p. 250).

Additionally, in relation to one of the most significant events for the world economy in 1974: the increase in oil prices, which conventional economic theory characterizes as an exogenous supply shock, Solow adds:

To get to the point, the conventional wisdom about 1974 seems perfectly acceptable. The economy was affected by a series of shocks, each of which could be seen as generating an upward increase in the domestic price level. Major shocks included the rise in oil prices by $O P E C$, the lagged effects of the depreciation of the dollar in 1971 and 1973, the fall in price and wage controls in 1974, and the global boom in oil prices. non-fuel minerals that began as the effect of an unusually synchronized rise in global demand in an industry with short-term inelastic supply and turned into a speculative boom. To these four shocks we can add, as already mentioned, the sharp increase in agricultural prices starting in 1973 and continuing until 1974, caused partly by crop shortages in the US and partly by strong demand, part of which was due in turn to poor harvests abroad (Ibid. p. 251).

Solow himself considers that "it is an abuse to describe all these events as supply shocks" because although some of them obviously are, such as the increase in the price of oil, the increase in import prices induced by depreciation and the grain shortage due to increased food prices; clearly there were elements on the demand side in the cases of food and non-fuel raw materials.

Further, the 1970s also witnessed a dramatic slowdown in the rate of productivity growth in industrialized nations. Measured by real per capita gross national product, productivity in the US grew at $2.8 \%$ per year between 1964 and 1973. 
In the countries of the European Organization for Economic Cooperation and Development (OECD) it grew by $3.7 \%$ during the same period. From 1973 to 1981, these rates fell to 1.3 percent in the United States and 1.5 percent in Europe (Shapiro, 1987, p. 6).

These two circumstances briefly described: supply shocks and a drop in productivity, among others, would lead to a shift in the emphasis of economic analysis; If from 1940 to 1970 this emphasis was focused on the aspects of demand, the subsequent years would see an extraordinary recovery on the importance of supply for economic analysis and secondarily on demand ${ }^{1}$.

\section{I.1 The Neoclassical Macroeconomics of Epidemics: supply shocks and individual decisions}

Barro (1986) in his text on Macroeconomics proposes: consider a displacement of the production function that lasts only the current period.

We can think of the bad weather that reduces coffee production in Brazil or the political problems that depress agricultural production in Poland. Recently, these types of changes have been called "supply shocks". For some reason, the term does not always apply to an adverse shock to the supply of goods. However, there may be a bountiful harvest or a streak of good luck in labor relations (p. 128).

In Barro's perspective, we can find a wide range of situations that we could qualify as supply shocks. From natural disasters, epidemiological, political conflicts, etc. which would be examples of triggering situations for supply shocks. In this sense, consider a purely parallel downward shift in the production function, for example, the result of a negative supply shock. Since this movement does not alter the slope of the production function -the marginal productivity curve of labor-, there are no substitution effects on the relative costs of consumption and leisure in the intertemporal utility function of individuals.

\footnotetext{
1 The economic-financial crisis of 2008-2009 has revealed the existing economic and social weaknesses in the current world order; the second decade of the 21 st century has seen the rebirth of studies related to the problems inherent to poverty, social polarization, inequality and their importance in determining the behavior of effective demand.
}

One effect of the supply shock is that production decreases for a given level of labor effort. Decreased production reduces wealth. However, because the change is short-lived, the wealth effects will be small. Therefore, says Barro:

"we find a small negative response from aggregate consumer demand and a small positive response from aggregate labor effort. The increase in work implies an increase in the goods offered. However, since the wealth effect is weak, this increase only offsets a small part of the initial reduction in supply. Thus, there is a net decrease in aggregate supply, which exceeds the small reduction in aggregate demand "(Ibid. P. 129).

Thus, Barro very clearly identifies a result derived from the presence of a negative supply shock: the drop in production. The treatment given by Barro to supply shocks and the decisions of individuals do not imply a generalization that coherently covers the specificities inherent in the consequences of a negative supply shock derived from an epidemic in the neoclassical perspective. More recent theoretical developments in this school of thought such as that of Eichenbaum et. to the. (2020) state:

In our model, an epidemic has effects on both aggregate demand and aggregate supply. The effect on supply arises, because the epidemic exposes the people who are working to the virus. People react to this risk by reducing their labor supply. The demand effect arises because the epidemic exposes people who buy consumer goods to the virus. People react to this risk by reducing their consumption. The effects of supply and demand work together to generate a large and persistent recession.

The work of Eichenbaum, Rebelo and Trabandt constitutes an extension of the canonical model called Susceptible, Infected and Recovered-Removed by its acronym: SIR model, proposed at the beginning of the 20th century by Kermack and McKendrick (1927) and constructed to explain the resulting equilibrium of the interaction between economic decisions and the dynamics of an epidemic. 
The SIR model developed by Eichenbaum et al, unlike that of Kermack and MaKendrick, considers the probabilities of transition between health states as endogenous, that is, they assume that the decisions of individuals resulting from the need to buy consumer goods and to work to generate purchasing power increases the chances of the infection spreading. These decisions exacerbate the depth of the recession caused by the epidemic. The resulting situation is not socially optimal because infected people do not internalize and do not take full responsibility for the consequences of their economic decisions for the spread of the virus. In this model, the simplest measure to contain the pandemic increases the severity of the recession, but saves approximately half a million lives in the case of the United States.

This brief review of neoclassical economic thought shows the existing conceptualization of the economic nature of a pandemic: it is an exogenous shock to the world economy with negative consequences on people's lives, economic activity and employment; The resulting trade-off between measures for social containment of the pandemic and preservation of human lives does not constitute a social optimum, and temporary health measures for containing the pandemic amplify the depth of the recession.

\subsection{Post-Keynesian Macroeconomics: Pandemics and the Utilization of Economic Capacity}

According to Lavoie (2006), as its name implies, post-Keynesians find their main inspiration in the work of John Maynard Keynes (The general theory of employment, interest and money), the famous British economist from the University of Cambridge. However, modern post-Keynesians are not limited to Keynes. They are also inspired by the work of those who were close to Keynes at the time he wrote the General Theory at Cambridge - such as Roy Harrod and Joan Robinson - and by those who were involved in creating the so-called "Cambridge school" in the fifties and sixties. Among these economists we find Nicolas Kaldor, Michal Kalecki and Piero Sraffa. For Serrano (2006) this school of thought has as its central axis the principle of effective demand.
Placing this principle at the center of the analysis means accepting that in market economies there is a shortage of demand rather than a shortage of supply, without this necessarily meaning that modern market economies cannot cope with supply problems.

Regarding the effects of a pandemic on economic activity and employment, from a postKeynesian perspective, Ken-Benedict (2020) argues that actions to stop the spread of the new coronavirus COVID-19 are drastically reducing economic activity, which that puts people out of work, puts significant pressure on companies and threatens a deep recession. In this perspective, the line of causality of the pandemic shifts from the measures of confinement and suspension of non-essential activities to a fall in effective demand (from the point of view of a company considered "non-essential", requiring that the company close your consumer-oriented outlets is more akin to a demand withdrawal for your goods or services than a voluntary labor withdrawal). Even without an order, public health messages encourage people to stay home as much as possible, which is directly experienced as a loss of demand.

At least in the US, when faced with rent payments and expenses for food, utilities and other necessities, many people do not have the option of retiring from their job. The cost of necessities is not small. For the US population as a whole, total housing, food at home, utilities, health insurance, and medications accounted for $39 \%$ of spending in 2018. For the fifth of the surveyed population with higher incomes low, those categories accounted for half of spending. Under a shelter-at-home order, households will likely see that share increase as they spend more on food and utilities, while they cannot easily cut spending on rent, health insurance or medicine. Without sufficient income, they must cut other expenses, including necessities like clothing. If they cannot negotiate a reduction or postponement of rent payments, they may face eviction (Ibid., P. 3)

Randrup, Olesen and Madsen (2020) consider that the global pandemic related to the COVID-19 virus and the consequent contraction in economic activity have currently led the world to a stalemate in 2020 , with the prospect of a prolonged and severe recession in the future. 
The exact magnitude of this impact on the world economy is, of course, uncertain, as is the duration of the current recession. However, many fear that the drop in the level of world GDP will be significant. In fact, probably on a similar scale if not worse than in the early years of the Great Recession.

Papadimitriou, Sezza F. and Zezza G. (2020) document the effects of the pandemic on economic activity in Italy and compare it with a group of countries, on which they state:

Although European countries did not act simultaneously, and at times followed different strategies, the impact of the epidemic was similar. If Italy had the largest drop in real GDP in 2020 / Q1, other countries were even more affected in the second quarter of 2020. In any case, the size of the economic shock is unprecedented (p. 4).

Additionally, in relation to the exogenous nature of the pandemic, a characterization supported by neoclassical theory, Keen (2020) affirms that the coronavirus is the result of excessive human pressure on the biosphere, and that the effects of the pandemic it has caused in the world have been aggravated by policy recommendations derived from conventional economic thought. In Keen's perspective, the current pandemic is not an exogenous variable to the world economic system created by the mind and hand of man, but the result of a way of relating to man with planet earth and its resources, in a way to create and consume satisfiers that have led to a predatory action of man on nature.

\section{Methodology}

\section{II.1 Method}

It is a quantitative research, with an exploratory scope, as it studies an ongoing phenomenon on which there are no previous studies in relation to the local dimension - read federal entity: Nayarit-; In this sense, it is a pioneering work that aims to contrast the local reality with the national reality. Additionally, it must be said that the proposed object is investigated from a macroeconomic perspective, incorporating the basic elements of the relevant theoretical debate in relation to the pandemic.
Space is opened to study the relationship between pandemic-economic activityemployment in an innovative way based on the elements provided by basic statistics. In this sense, it is intended to provide cognitive elements that allow a better understanding of the relationship between the proposed variables. The approach presented establishes the bases for subsequent studies that address the problem of causality between economic activity and employment, a central problem that remains in the macroeconomic debate exposed in the literary review. This study lays the foundations for, in another space, elucidating the exchange between economic losses (unemployment) and public policy actions (health and government management) among the states in our country.

\section{II.2 Databases}

The following databases have been used to explore the pandemic-economic activity-formal employment relationship: for information related to the number of infected and deaths in the world, data from the World Health Organization (WHO) are used . Graphs and tables on the daily evolution of the pandemic in the world are presented, organized by region and by country. In the case of the pandemic data on federal entities, the official data provided by the Government of the Republic through the Ministry of Health is used.

Data on economic activity are documented with the Global Indicator of Economic Activity (IGAE) in Mexico, which allows us to know and monitor the behavior of the real sector of the economy in the short term; and in the case of Nayarit, the Quarterly Indicator of Economic Activity (ITAE) is used, both reported by INEGI. To identify the global dynamics of labor activity in Mexico, the Global Index of Employed Personnel in Economic Sectors (IGPOSE) is used.

This indicator has been constructed based on the 2014 Economic Censuses (data from 2013) and is provided by INEGI. The information related to formal employment in Mexico was obtained from the Ministry of Labor and Social Security (STPS) and those of Nayarit from the Mexican Institute of Social Security (IMSS). 
The graphing of the mentioned time series shows the effects of the pandemic on people's lives, economic activity and formal employment. The data related to economic activity and formal employment for the Mexican economy and Nayarit are put into a growth rate format, which allows comparing the current crisis with other moments in time such as the economic-financial crisis of 2008-2009.

\section{Results}

\section{III.1 Spatial dimension of Covid-19 in the world, Mexico and Nayarit}

On December 31, 2019, the World Health Organization (WHO) received reports of the presence of pneumonia, of unknown origin, in the city of Wuhan, China; On January 4, 2020, said organization would officially register the first case of infection by SARS-CoV-2, the virus that causes the disease known as Covid-19 and that currently plagues the entire world.

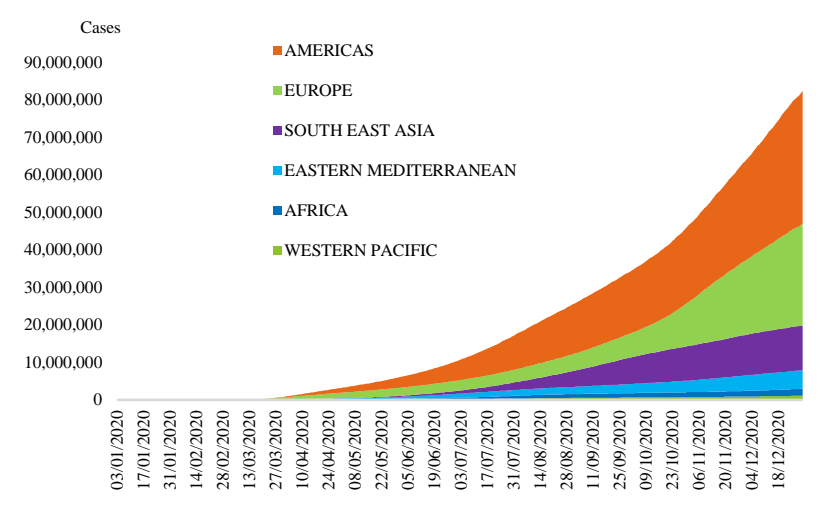

Figure 1 Number of Covid-19 patients by regions in the world, December 29, 2020, WHO

Source: https://covid19.who.int/

Figure 1 shows the dynamics of spatial contagion in the number of Covid-19 patients in the different regions that make up our planet. Four moments describe the spread of the virus: the first, is the moment of the epidemic outbreak - located in the graph on January 4 -, the moment in which the health authorities in China communicate to the World Health Organization that they face a new disease caused by a new virus where the highest number of infected are located in that country and a few in Korea and Japan. The second moment is located two months later; On March 4, 2020, the virus has moved its vortex to Europe, notably Spain and Italy, and cases are beginning to be detected in England and France.
Europe is the new epicenter of global contagion but there are already cases detected in all regions of the world: the pandemic is a reality and a threat to most of the public health systems in the world, which, it is recognized, is not recognized. They are prepared to face a pandemic of such magnitudes.

In the third moment, from April to the end of September, the central focus of contagion shifts to the American continent, making visible from June also very importantly, the Southeast Asian region made up of countries such as India, Bangladesh, Indonesia, Nepal, Thailand, SriLanka, etc. The fourth moment begins in October and continues to this day with a regrowth in Europe and the Americas region, which is seen much more clearly in Figure 2 on the number of deaths.

By far, the American continent has contributed the highest share in absolute and relative terms relative to the rest of the world: $34,836,259$ patients in the Americas versus only 1,072,314 in the western Pacific region (China, Japan, Korea, Bangladesh, etc.), (WHO, December 29, 2020; in relative terms per million inhabitants, the United States has a contagion rate of 58,449 against 66 in China (WHO, December 31, 2020).

In relation to the number of deaths by regions in the world, once again the Americas region accounts for the highest number of deaths from Covid-19, these being a total of 845,385 against only 19, 774 deaths in the Pacific region of the west (WHO, December 29, 2020). In relative terms per million inhabitants, the United States has a rate of 1,014 deaths against 3 in China (WHO, December 31, 2020). In relation to this indicator, the regrowth that started in Europe in early November, continued in December and is expected to persist with the December Christmas festivities and the presence of the effects of seasonal influenza is highly worrying (see Figure 2). 


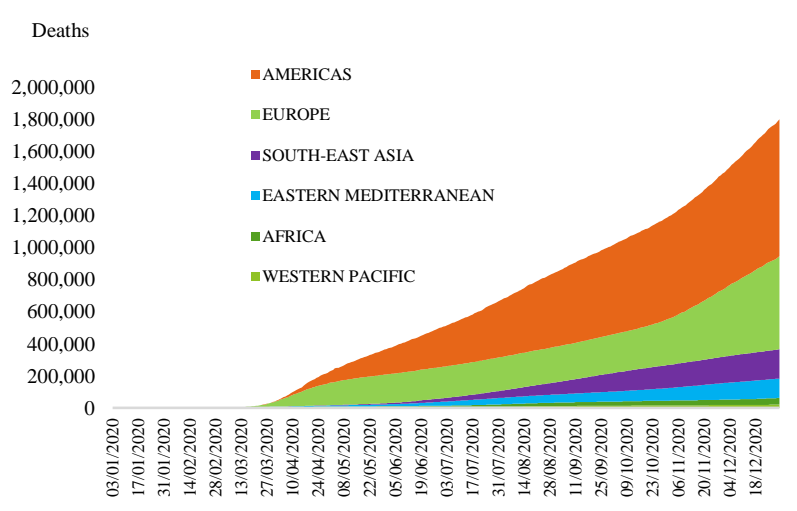

Figure 2 Number of deaths from Covid-19 by region in the world, December 29, 2020, WHO

Source: https://covid19.who.int/

The importance of relativizing the absolute data generated by the present pandemic is an issue of the greatest importance since the media tend to overestimate the value of the data in absolute terms, sometimes deforming the real dimension of the public health problem.

In this sense, in absolute numbers, as can be seen in the left side of Figure three, Mexico occupies the position number twelve in the world with 1,383,434 patients and number four with 122,426 deaths, a situation that is observed on the right side of the same Figure (WHO, December 29, 2020); On the other hand, in terms of population, Mexico ranks 62nd for accumulated Covid-19 cases and 12th for deaths when said data per million inhabitants are relativized (WHO, August 24, 2020).
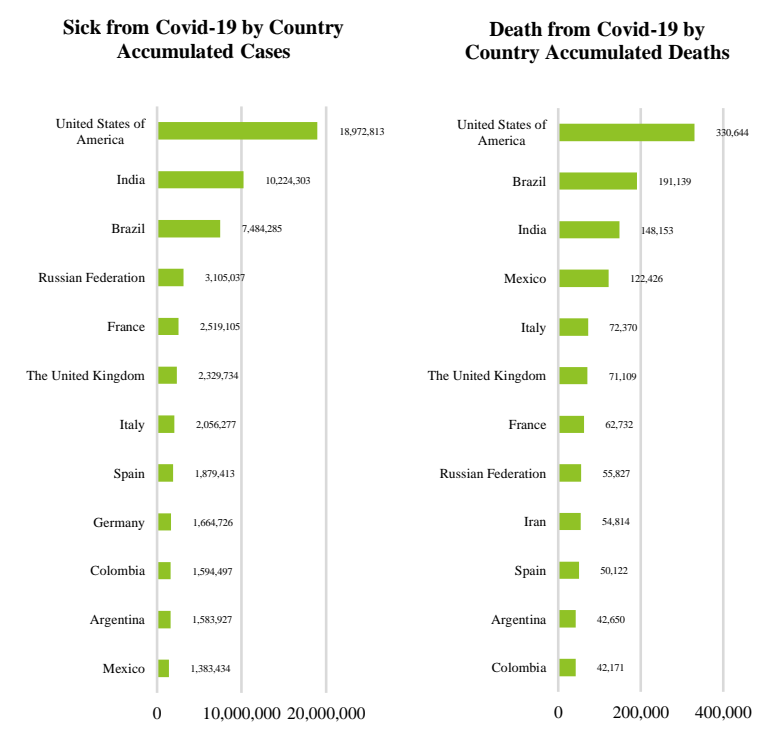

Figure 3 Sick and deaths from Covid-19 by country; WHO, December 29, 2020

Source: https://covid19.who.int/table
In relation to the behavior of the spread of the virus in the states that make up the Mexican Republic, as can be seen in Figure 4, this differentiation allows us to observe that in absolute terms the states with the highest incidence of Covid-19 patients are: Federal District, State of Mexico, Guanajuato, Tabasco, Veracruz, Nuevo León, Puebla, Tamaulipas and Sonora; while those with the lowest incidence are: Colima, Zacatecas, Nayarit, Morelos and Aguascalientes.

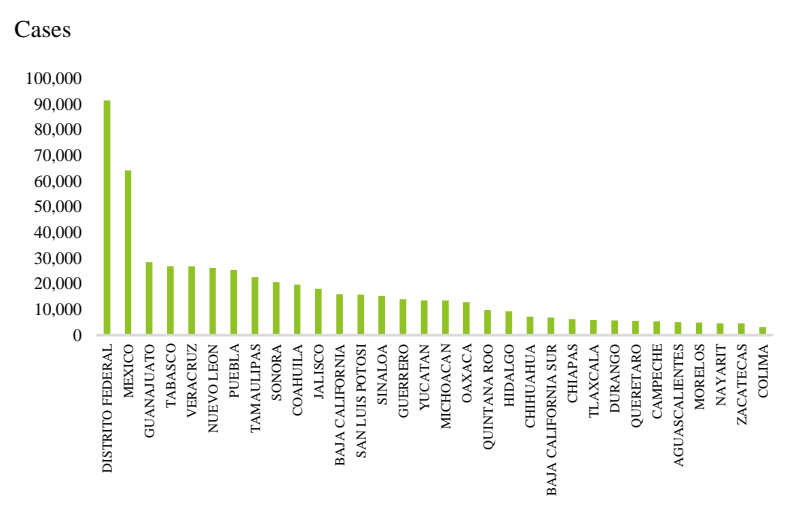

Figure 4 Covid-19 patients by federal entity in Mexico as of August 22, 2020, accumulated cases

Source: Mexico's Government

In relative terms, that is, the total number of patients in relation to the total population, the first five places are Tabasco, Federal District, Baja California Sur, Sonora and Tamaulipas. The last five places for the same indicator are Chiapas, Chihuahua, Jalisco, Morelos and Querétaro. In this area, Nayarit is located in position number 20 , a situation that can be seen in Figure five.

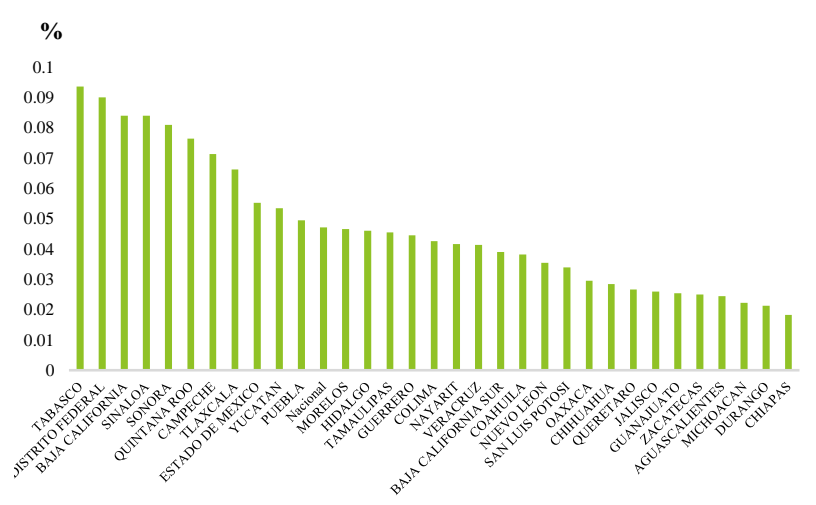

Figure 5 Deaths in relation to the total population by federal entity in Mexico as of August 22, 2020 Source: Mexico's Government

Also, in the ratio of deaths to the total population, Nayarit is below the national average, reaching position number 17 (Government of Mexico, August 22, 2020). 
Apparently, neither by the total number of patients in absolute values or relative to the population or in number of deaths Nayarit would have a serious problem; but that is only in appearance; As can be seen in Figure 6, by availability of hospital beds, Nayarit ranked first in the nation in terms of least availability of beds with an occupancy of $68 \%$ and only $32 \%$ available. This data has constituted an indicator of permanent pressure and attention for the political authorities and the health sector in the state who have made it known knowing the serious social implications that this fact has. In terms of availability of beds with a fan, Nayarit has $26 \%$ occupancy and $74 \%$ availability, occupying the 21st position among the group of states (IRAC Network, accumulated from August 23, 2020. SSA / SPPS / DGTI / State Health Services).

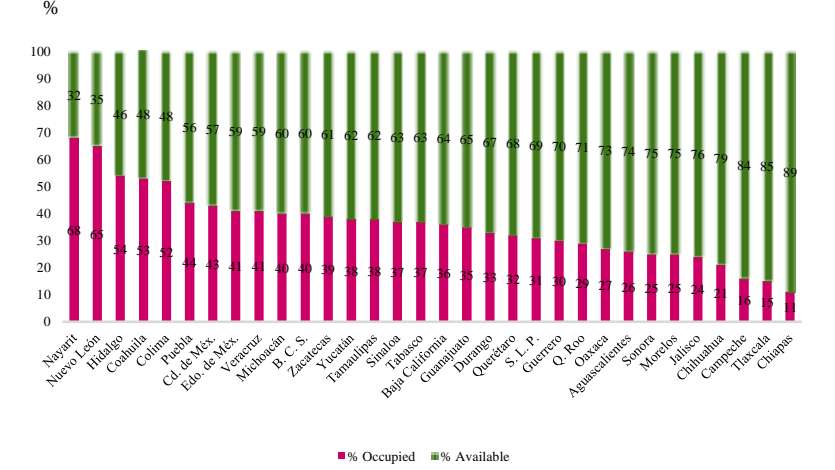

Figure 6 Mexico: Availability of general hospital beds, August 22, 2020

Source: IRAC Network, accumulated from August 23, 2020. SSA / SPPS / DGTI / State Health Services

Nayarit is a federative entity with a relatively low problem of patients and deaths from Covid-19, but with a serious public health problem due to the low number of hospital beds in the entity; A situation that, as we can see in Figure 7, is a characteristic of Mexico compared to other Latin American countries. Mexico has the lowest number of beds per 1000 inhabitants compared to Argentina, Brazil, Chile and the United States; However, in terms of hospitals per million inhabitants, Mexico has a higher number compared to Argentina, Brazil and Chile and the average for Latin America.

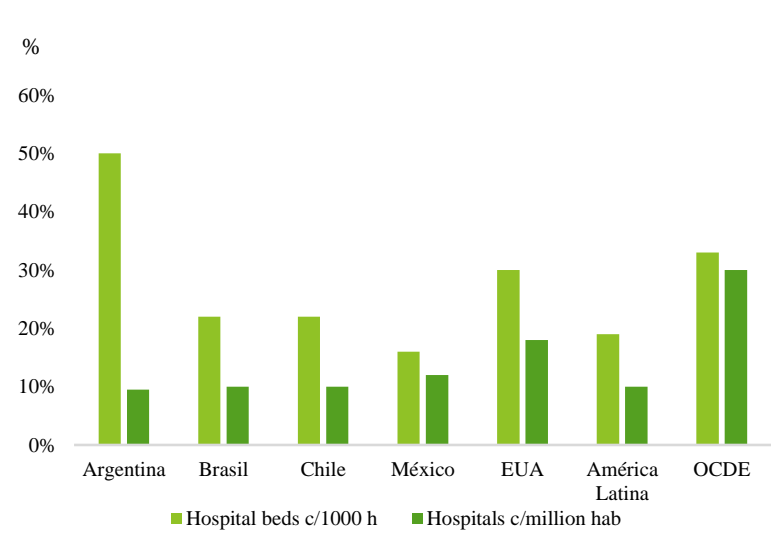

Figure 7 Hospital infrastructure Source: OMS, 2020

In the perspective briefly outlined in the previous paragraphs, it can be seen that there is no region of the planet, the American continent and Mexico that has not been affected to a greater or lesser degree by the effects of the pandemic. The measures of confinement and suspension of non-essential activities have had an immediate effect on economic and labor activity. These impacts are described below.

\section{III.2 Sectorial economic activity and formal employment in Mexico}

\section{III.2.1 Sectorial economic activity}

Ten months ago, long before the preventive measures that forced civil, military and private authorities, as well as the agencies and entities of the three orders of government, to implement preventive measures against disease caused by the SARS-CoV2 virus (COVID-19), among which the temporary suspension of activities of the public, social and private sectors that involve the physical concentration, transit or movement of people, the global indicator of economic activity (IGAE) in Mexico had experienced ten consecutive months of negative economic growth. The IGAE, as is known, allows to know and monitor the evolution of the real sector of the economy in the short term. In Figure 8 we can see how, since May 2019, the percentage changes in the real sector of the Mexican economy have been negative and those related to the months of April and May are deeper than the crises of 1995 and 2009. It is in this sense that it is affirmed that the current economic crisis is only comparable with the great crisis of 19291932 of the last century. 


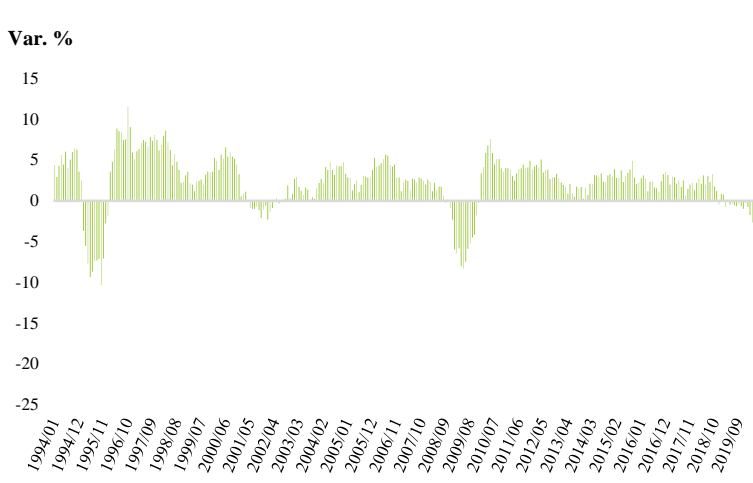

Figure 8 Global indicator of economic activity (IGAE) in Mexico, 1994-June 2020, seasonally adjusted series, annual variation

Source: INEGI

With the suspension of non-essential economic activities, the recession of the Mexican economy would deepen during the months of the day of healthy distance: $-2.6 \%$ in March, $-19.6 \%$ in April and $-21.6 \%$ in May, a situation that can be observed In table 1 . It is observed that industrial activity decreased $-4.8 \%$ in March, $-29.7 \%$ in April and -29.7 in May; the services sector decreased $-2.1 \%$ in March, $15.9 \%$ in April and $-19.1 \%$ in May.

\begin{tabular}{|c|r|r|r|r|}
\hline $\begin{array}{c}\text { Year- } \\
\text { month }\end{array}$ & $\begin{array}{c}\text { IGAEE } \\
\text { Percentage change compared to the same month of the } \\
\text { previous year }\end{array}$ \\
\hline $2020 / 03$ & -2.6 & 8.1 & -4.8 & -2.1 \\
\hline $2020 / 04$ & -19.6 & 1.4 & -29.7 & -15.9 \\
\hline $2020 / 05$ & -21.6 & 2.5 & -29.7 & -19.1 \\
\hline
\end{tabular}

Table 1 Annual\% variation of the Global Index of Economic Activity (IGAE) in Mexico by sector, MarchMay 2020

Source: INEGI

Behind the negative growth rates of the global indicator of economic activity are the severe impacts that social confinement measures have had on industry and services. In the case of the IGAE of the industrial sector of our country, it has experienced 20 consecutive months of negative economic growth: from October 2018 to May 2020, industrial activity has been decreasing steadily, deepening these falls in the months of April and May of this year as a result of the pandemic.

The explanation for the fall of the industrial IGAE is found in the conjunction of disinvestment processes existing before the economic crisis generated by Covid-19 that are articulated with the processes caused by the pandemic in the world.
Specifically: the 78 months of negative growth that mining has experienced from March 2013 to May 2020 out of a total of 88 months that have elapsed; in the 22 months of negative economic growth in the construction sector from August 2018 to May 2020 and in the 8 months of constant decline in manufacturing from October 2019 to May 2020. In the case of these three industrial activities, What the pandemic has done is to make the fall deeper, deeper, a situation that can be seen in Table 2 .

\begin{tabular}{|l|c|r|r|r|}
\hline $\begin{array}{l}\text { Year- } \\
\text { month }\end{array}$ & $\begin{array}{c}\text { Mini } \\
\text { ng }\end{array}$ & $\begin{array}{c}\text { Secondary sector } \\
\text { Engy, water } \\
\text { and gas }\end{array}$ & $\begin{array}{c}\text { Buildi } \\
\text { ng }\end{array}$ & $\begin{array}{c}\text { Manufac } \\
\text { ture }\end{array}$ \\
\hline $2020 / 03$ & 1.9 & -0.6 & -7.0 & -6.4 \\
\hline $2020 / 04$ & -3.8 & -3.4 & -38.4 & -35.6 \\
\hline $2020 / 05$ & -5.8 & -12.9 & -35.9 & -35.6 \\
\hline $\begin{array}{l}\text { Note: percentage change with respect to the same } \\
\text { month of the previous year. }\end{array}$ \\
\hline
\end{tabular}

Table 2 Annual\% variation of the Global Index of Economic Activity (IGAE) of the Sector Secondary in Mexico, March-May 2020

Source: INEGI

With its own and different dynamics, the services sector also contributes to explain the negative behavior of the IGAE of the Mexican economy.

Unlike the industrial sector, services had been growing positively in a sustained and constant way until before the Covid-19 crisis. As expected, activities related to wholesale and retail trade, transport and media, cultural and sports entertainment, and hotels and food and beverage preparation fell sharply, with the increase being spectacular. of hotels and food and beverage preparation: $-70.4 \%$ in April and $72.1 \%$ in May, situation that can be seen in Table 3.

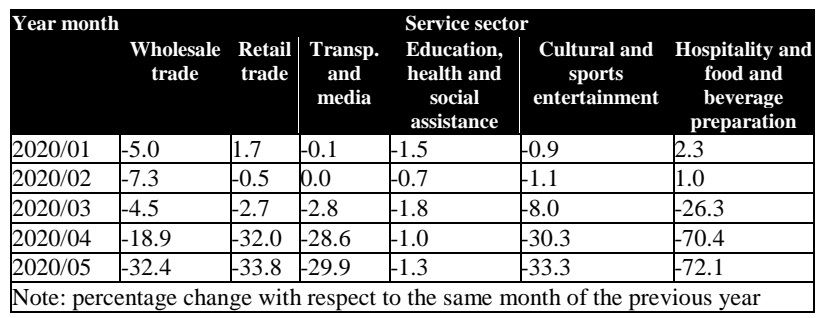

Table 3 Annual\% variation of the Global Index of Economic Activity (IGAE) of the Sector Services in Mexico, January-May 2020

Source: INEGI 


\section{III.2.2 Labor dynamics in the Mexican economy}

To identify the global dynamics of labor activity in Mexico, the Global Index of Employed Personnel in Economic Sectors (IGPOSE) is used. This indicator has been constructed based on the 2014 Economic Censuses (data from 2013) which report a total of 21.6 million employed persons in our country, of which approximately $89.0 \%$ are working in the five economic sectors contemplated in the calculation of the IGPOSE (construction companies, manufacturing industries, wholesale and retail trade and non-financial private services) and represents, using econometric methods, a very adequate approximation of the employed personnel of the non-agricultural sectors, complements the information generated in households, shows the evolution of this variable for the economy as a whole and serves as input for the analysis, monitoring and decision-making of the various sectors of society.

As can be seen in Figure 9, since June 2018 a decreasing trend has been observed in the global index of employed personnel in the economic sectors (IGPOSE) as a result of the fall in economic activity in the industrial sector to which they are going to come to add the effects of the pandemic on the industrial and services sectors, which will cause the IGPOSE to be negative during the months of March, April and May: $-1.12 \%,-4.83 \%$ and $-6.91 \%$ respectively. It can also be seen that the depth of the fall in May exceeds $-6.3 \%$ in May of the 2009 international financial crisis. In said crisis, IGPOSE experienced 15 consecutive months of negative economic growth, in this sense the The current crisis is still unknown because it is still ongoing and its future is uncertain and unpredictable.

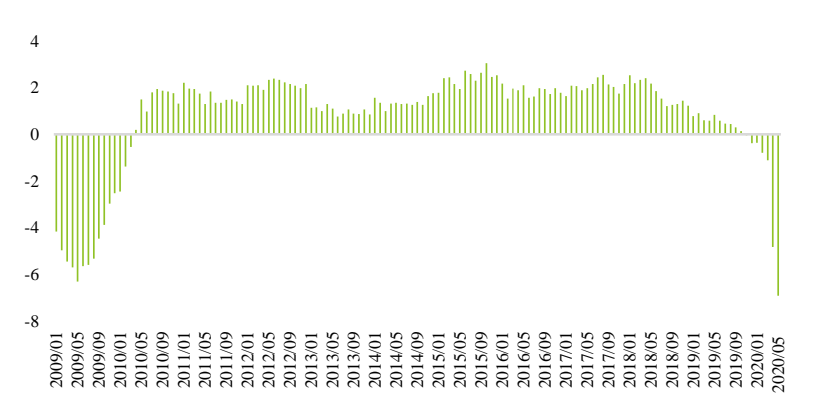

Figure 9 Global Index of Employed Personnel of Economic Sectors in Mexico, 2009-june 2020, seasonally adjusted figures. Annualized variation. Base $2013=100$ Source: INEGI
A perspective that complements the perspective offered by the index described above is the one offered by the behavior of the so-called formal employment, that is, the one registered with the Mexican Institute of Social Security (IMSS) and which allows us to account for the state that keeps the economic activity of the formal sector of the economy.

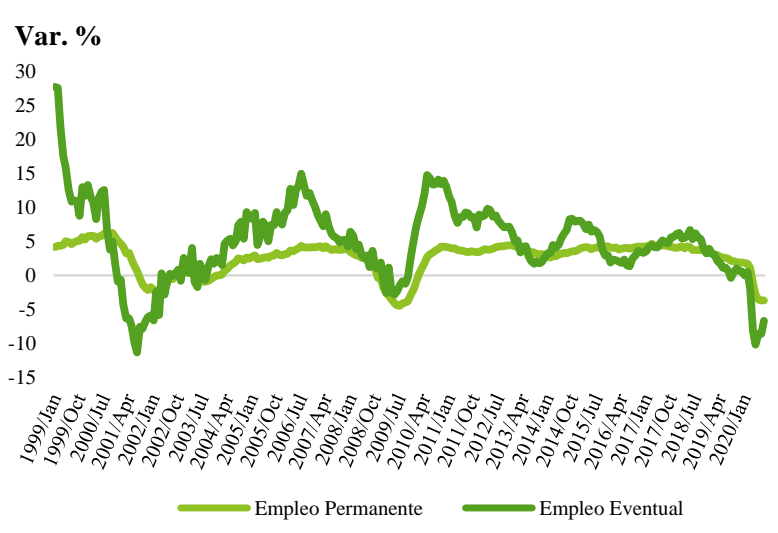

Figure 10 Growth in permanent and temporary employment registered with the IMSS, 1999-August 2020 Source: INEGI

As can be seen in Figure 10, the lowest growth rate has been related to temporary employment: $-8.58 \%$ in the month of July 2020 , much deeper than the $-2.83 \%$ of the month of May in the crisis of 2009 and very close to the $11.32 \%$ of the month of July 2001 . For its part, the behavior of permanent employment is much more stable, although in the crisis of 2009 its fall was deeper than that of temporary employment: $-4.46 \%$ in the July, while temporary employment only fell $-2.8 \%$ in May 2009. The volatility of temporary employment is given by its standard deviation which is 5.69 while that of permanent employment is 2.32 .

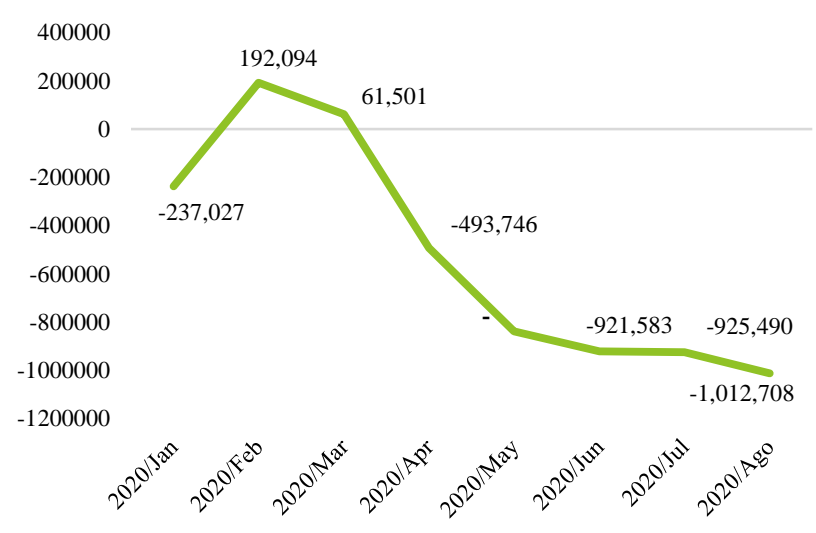

Figure 11 Formal jobs generated accumulated in Mexico, January to August, 2020

Source: STyPS 
Figure 11 shows the accumulated number of permanent and eventual formal jobs lost due to the pandemic during the months of April, May, June and July, this being the amount of 925,490 jobs lost as of July 2020.

\section{III.3 Sectorial economic activity and formal employment in Nayarit}

\section{III.3.1 Sectorial economic activity}

The dynamics of the Nayarit economy is determined for the most part by the link with the dynamics of the national economy: with the agricultural sector, services and industry; to a lesser degree with the exterior through tourism, foreign investment, remittances, agricultural exports and migration. The negative economic growth experienced by the Mexican economy since May 2019 would negatively impact the dynamics of the Nayarit economy, causing, as can be seen in Figure 12, the July-September and October-December 2019 quarters to be negative: -3.3 and $-1.0 \%$ respectively, but also the first and second quarters of 2020 with $-3.1 \%$ and $-23.1 \%$ respectively.

Additionally, it must be added that the Nayarit economy did not grow in any quarter throughout 2018: $-0.3 \%,-2.7 \%,-0.0 \%$ and $0.9 \%$, first, second, third and fourth quarters respectively of 2018.

The context briefly described prior to the Covid-19 crisis determines a negative expectation for the second and third quarters of 2020, which show the effects of the Covid-19 crisis with greater depth than those experienced previously.

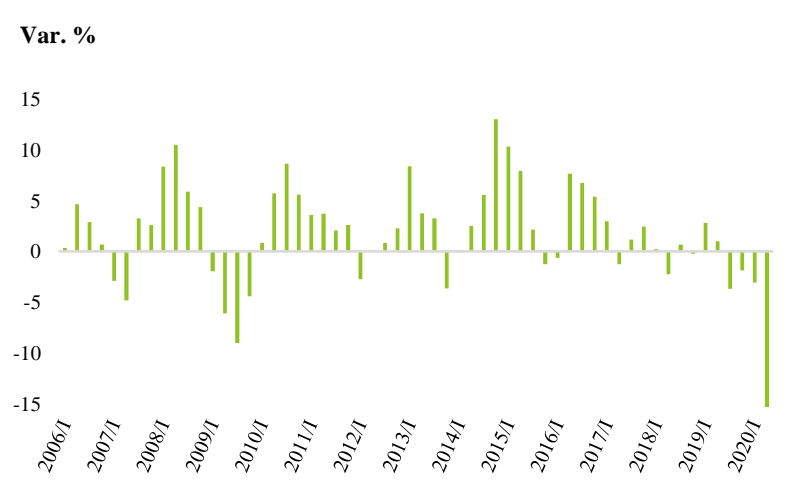

Figure 12 Quarterly indicator of state economic activity in Nayarit, 2006-2020/IIT

Source: INEGI
In line with what is happening with the national economy, the poor performance of the Nayarit economy is mainly explained by the negative economic growth of the industrial and service sectors of Nayarit. In the case of the industrial sector, in line with the national economy, it is observed that mining has experienced negative growth rates since the second quarter of 2017; Likewise, the construction sector has experienced negative economic growth rates since the third quarter of 2015 , a situation that is very similar to those experienced by the energy, water and gas and manufacturing sectors. These trends, which are medium and long-term trends largely express the influence of the Mexican economy on the economy of Nayarit, this situation can be seen in Figure 13. The outlook for the third and fourth quarters of 2020 is that they will be negative, although of less depth than that observed in the first and second quarters of 2020, which were $16.4 \%$ and $-26.9 \%$ respectively.

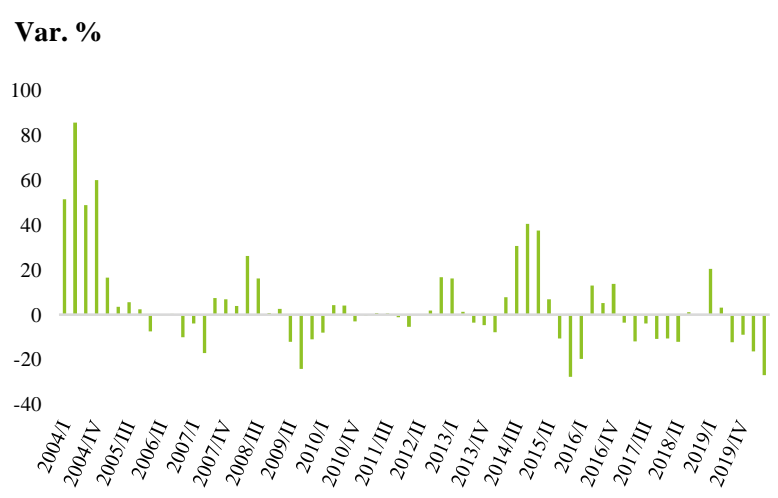

Figure 13 Quarterly indicator of the economic activity of the Secondary Sector in Nayarit, 2004-2020/IIT Source: INEGI

Similarly, the services sector of the Nayarit economy has also contributed to negatively impact the economy as a whole as expressed by the Quarterly Indicator of State Economic Activity until the second quarter of 2020 for which information is available. Figure 14 shows how since the first quarter of 2019 the service sector of the Nayarit economy has experienced negative economic growth rates: $0.7 \%,-1.0 \%,-1.8 \%,-0.8 \%,-0.8 \%$ and $-23.8 \%$ during quarters I, II, III and IV of 2019 and first and second quarters of 2020 respectively. One of the most representative components of the services sector is commerce, which had been experiencing negative growth rates from the second quarter of 2018 to the fourth quarter of 2019 , slightly improving in the first quarter of 2020 with $0.3 \%$ positive economic growth.

MENDOZA-ALVARADO, Juan José, ROBLES-ZEPEDA, Francisco Javier and SÁNCHEZ-GÓMEZ, Sara Alejandra. Covid-19, economic activity and formal employment. A look at the effects of the pandemic in México and Nayarit, 2020. RINOE Journal-Macroeconomics and monetary economy. 2020 


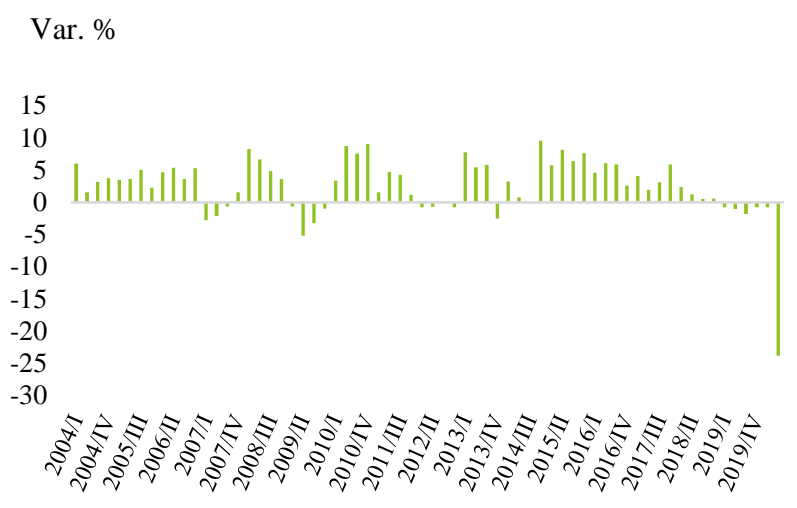

Figure 14 Quarterly indicator of the economic activity of the Tertiary Sector in Nayarit, 2004-2020/IIT Source: INEGI

The expectation of economic growth in the services sector of the Nayarit economy for the third and fourth quarters of 2020 is negative, which will accumulate practically two consecutive years without growing.

\section{III.3.2 Formal employment in Nayarit}

Formal employment generated by the private sector in Nayarit until June 2020 was 144,319, which is the sum of permanent and temporary workers, a magnitude described in Figure 15 by the blue line, which reflects a significant drop in relation to the 159,617 workers reported in February of that same year. In terms of percentage variation, as can be seen in Figure 16, the 7,060 total jobs generated during the month of January 2020 (6,436 temporary jobs and 624 permanent jobs) constituted the second most important percentage variation in the economic history of formal employment in Nayarit during the last twenty years: $12.57 \%$; only surpassed by the $17.31 \%$ registered in June 2004.

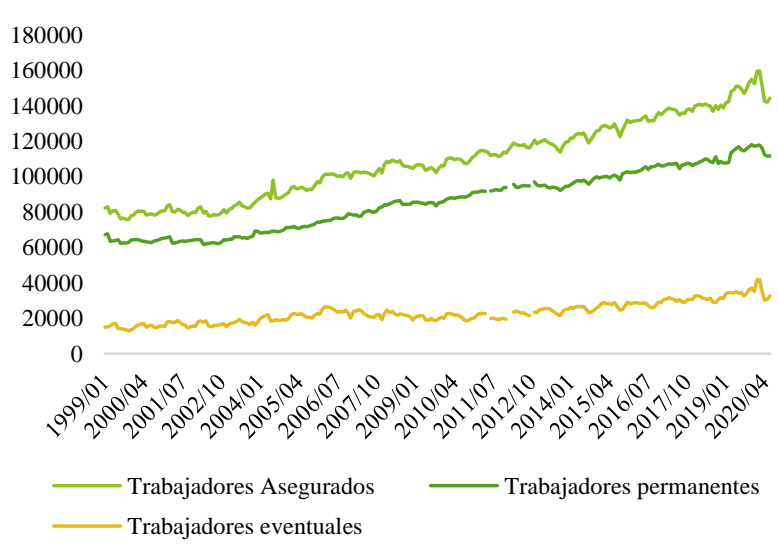

Figure 15 Evolution of the total number of Workers affiliated to the IMSS in Nayarit, 1999-June 2020 Source: IMSS
A fact that draws the attention of this analysis consists of the discordance existing between the fall of $-3.1 \%$ in the first quarter of 2020 of the quarterly indicator of state economic activity (ITAEE) of Nayarit which, it is observed, marginally affects formal employment. Despite the fall in economic activity in the first quarter of 2020, total employment affiliated with the IMSS grew at rates of $12.57 \%, 12.24 \%$ and $2.26 \%$ during January, February and March of the mentioned year.

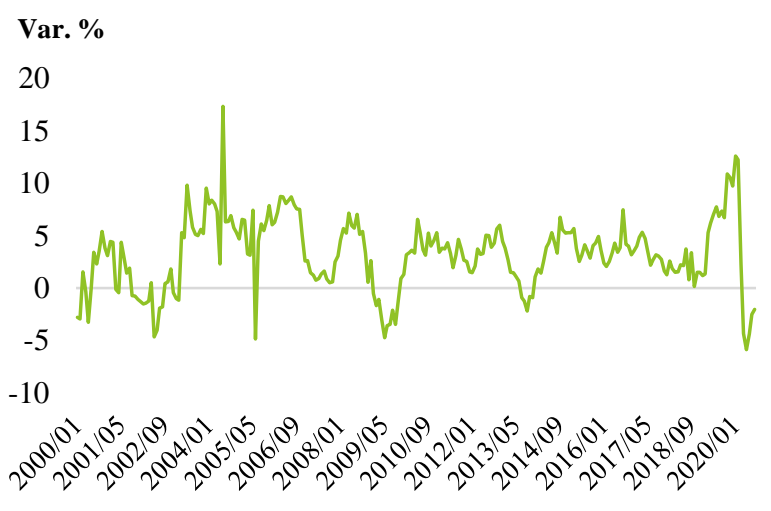

Figure 16 Growth rate of the total number of workers affiliated to the IMSS in Nayarit, 2000-August 2020 Source: IMSS

But, although formal employment shows some resistance to endogenous economic slowdown processes, this is not the case with the ravages caused by the Covid-19 effect.

With data from the Mexican Social Security Institute (IMSS) up to June 2020, as can be seen in Figure 17, the spectacular job creation in January and February decreases significantly during the month of March, which records a loss of $-7,784$ jobs reaching its lowest point in the month of April with -17,181 jobs lost.
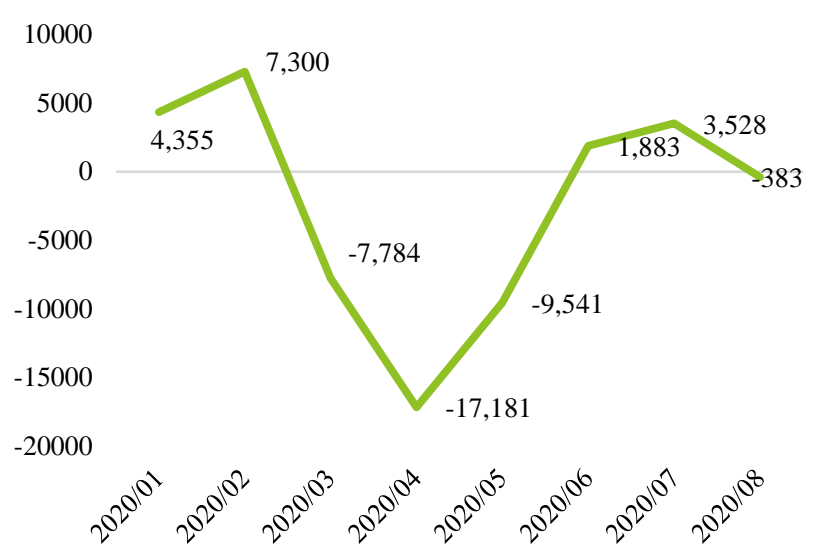

Figure 17 Formal jobs generated accumulated in Nayarit, January-June 2020

Source: IMSS 
Notwithstanding the foregoing, the loss of formal employment decreases during the month of May, with only $-9,541$ jobs lost, and in June there were 1,883 jobs generated accumulated from January to June 2020.

The articulation of existing economic processes in the Nayarit economy in the medium and long term prior to the pandemic, added to those of Covid-19, constitute a similar fact, in terms of formal employment, to that registered during the 2009 crisis. Observe in Figure 17, the drop in formal employment in the Nayarit economy of $-5.86 \%$ during the month of May 2020 is higher than the $-4.73 \%$ of May 2009 .

The above said in absolute terms means that in the crisis of the Covid-19 of 2020, 17,181 formal jobs were lost, while in the economicfinancial crisis of 2009, 6,493 formal jobs were lost in the Nayarit economy. It is in this sense that it can be affirmed that the depth of the economic crisis caused by the pandemic is greater than that caused by the economicfinancial crisis of 2009.

\section{Conclusions}

1. In relation to the effects of the pandemic on economic activity and employment, both the neoclassical and postKeynesian schools point out the existence of negative effects on both the supply and demand sides; They also agree that their magnitudes are amplified due to the temporary public health restrictions imposed such as social confinement and the suspension of non-essential activities. Despite this apparent coincidence, the analytical-conceptual and methodological frameworks that characterize and differentiate both schools of economic thought lead them to this result in different ways. In this way, neoclassical theory considers that the transmission mechanism of the pandemic occurs on the supply side, that is, on the side of the reduction in the number of workers who come to work, negatively impacting the supply of goods and services and secondarily on consumption (demand).
For post-Keynesian thought, the line of causality of the pandemic moves from the measures of confinement and suspension of nonessential activities to a fall in effective demand (from the point of view of a company considered "non-essential", requiring that the company closing its consumer-oriented outlets is more similar to a withdrawal from demand for its goods or services than to a withdrawal of voluntary labor). Even without an order, public health messages encourage people to stay home as much as possible, which is directly experienced as a loss of demand.

2. Due to its effects on economic activity and employment, in Mexico and Nayarit, we are facing one of the deepest economic and labor crises in our economic history, deeper than the economic-financial crisis of 2008-2009 and in In many ways comparable to that of 1929 . There is a $-21.6 \%$ drop in economic activity in Mexico in the month of May 2020 and a $-23.1 \%$ drop in the case of the Nayarita economy in the second quarter of the same year. The drop in economic activity called hotels, food preparation and beverages is the deepest for the Mexican economy: $-70.4 \%$ in April and $-72.1 \%$ in May. In relation to formal employment, a loss of 925,490 jobs was recorded as of July for the Mexican economy as a whole and of 17,181 jobs for the Nayarit economy as of April 2020.

3. In relation to the apparent exogeneity of the pandemic, assumed by neoclassical economic thought, post-Keynesianism proposes that said virus has an endogenous character, insofar as it is the result of excessive human pressure on the biosphere, and that the effects of the pandemic it has caused in the world have been exacerbated by policy recommendations derived from conventional economic thinking. It is a phenomenon about which, we know that it can be caused by the historical way in which the human being relates to nature at the present time.

\section{References}

Acemoglu, D., Chernozukov, V., Werning, I. and Whinston, M., (2020). Optimal Targeted Lockdowns in a Multi-Group SIR Model. Working Paper 27102, National Bureau of Economic Research, May. 
Alon, T., Doepke, M., Olmstead-Rumsey, J., and Tertilt, M. (2020). The Impact of COVID-19 on Gender Equality. Working Paper 26947, National Bureau of Economic Research April.

Asenjo, O. (1993). El mercado de trabajo como institución social. España, Revista de Economía Aplicada, Núm. 3, (vol. 1), págs. 213-217.

Barro, R. (1986). Macroeconomía. México, Edit. McGraw-Hill.

Eichenbaum, M. S., Rebelo, S. and Trabandt, M. (2020). The macroeconomics of epidemics. National Bureau of Economic Research (NBER), working paper 26882.

Fernández-Villaverde, J. and I. Jones, C. (2020). Macroeconomic Outcomes and COVID-19: A Progress Report. Brooking Papers on Economic Activity, Conference Drafts, September.

Ken-Benedict, E. (2020). Macroeconomic impact of the public health response to COVID19. Post-keynesian Economics Society, Working paper 2011.

Kermack, W. O. and Anderson G. M. (1927). A Contribution to the Mathematical Theory of Epidemics, Proceedings of the Royal Society of London, series A 115, no. 772, pp. 700-721. Recuperado de: https://royalsocietypublishing.org/doi/10.1098/r spa.1927.0118

Lavoie, M. (2006). Introduction to PostKeynesian Economics. Edit. Palgrave MacMillan.

Papadimitriou, D., Zezza, F and Zezza, G. (2020). When will Italy recover? Edit. Levy Economics Institute of Bard College, October.

Randrup, B. M., Olesen, F. and Ove Madsen, M. (2020). COVID-19 and the global recession -the imperative need for a Keynes solution. Publicado en ResearchGate, recuperado de: https://www.researchgate.net/publication/34104 9572 COVID-19 and the global recession -the imperative need for a Keynes solution

Ros, J. (2012). La Teoría General de Keynes y la macroeconomía moderna. México, Investigación Económica, vol. LXXI, pp. 19-37.
Serrano, F. (2006). Pensamiento postkeynesiano y pensamiento marxista, en Alicia Girón (coordinadora), Confrontaciones monetarias: marxistas y post-keynesianos en América Latina. Edit. CLACSO Libros, pp. 1928.

Shapiro, M. D. (1987). Supply shocks in Macroeconomics. National Bureau of Economic Research (NBER), working paper No. 2146.

Solow, R. M. (1980). What to do (Macroeconomically) When OPEC comes? in Rational expectations and Economic Policy, Stanley Fisher, Edit. University of Chicago Press. Recuperado de: https://www.nber.org/system/files/chapters/c62 66/c6266.pdf

Keen, S. (2020). El coronavirus expone brutalmente las falacias de la economía neoclásica y la globalización. Revista de Economía Institucional, 22(43), 17-27. DOI: https://doi.org/10.18601/01245996.v22n43.02. 